and an account of an insect discovered to inhabit the cellular membrane of that bird. Mem. Wernerian nat. hist. soc., vol. i, p. 176-193, pl. vii, figs. 1-3.

Murray, A.

'77. Economic eritomology, Aptera. Scribner, Welford, and Armstrong, N. Y.

Robertson, C.

'66. Note on an undescribed species of Acarus found in the pigeon, Columba livia. Quart. journ. micr. sc., n. s. vol. vi, p. 20I-203, 4 figs. Abstracted in Amer. nat., vol. iii, p. 389 .

Robin, Ch., ANd Mégnin, P.

'77. Mémoire sur les Sarcoptides plumicoles. Journ. anat. et physiol., tom. xiii, p.
209-248, pl, xi-xii, p. 391-429, pl. xxiixxv, p. 498-52I, pl. xxvi-xxix, p. 629-656, pl. xxxvi-xxxviii.

Slosarsky, A.

'77. On the anatomy and systematic position of Hypodectes columbae, n. sp. Warsaw, I877, I4 pp., I pl. (In the Russian language.)

Trouessart E.-L. et Mégnin, P.

'85. Les Sarcoptides plumicoles ou Analgésines. I. Les Ptéroliches. Journ. de microgr., tom. viii, p. 92-IOI, I50-157, 2 I I-2 I9, 257-266, 33 I-338, 380-385, 428436, 527-532, 572-579, tom. ix, p. 63-7o, I09-I17. Also published separately, Paris, A. Doin, 8o., 84 pp., i7 figs., 2 pl.

\title{
NOTES ON SOME MELOIDS, OR BLISTER BEETLES, OF NEW MEXICO AND ARIZONA.
}

BY C. H. TYLER TOWNSEND, KINGSTON, JAMAICA.

The blister beetles form quite an important and characteristic feature of the coleopterous fauna of the southwest. I remember that the only entomological specimens that I could find in the Museo nacional, in the City of Mexico, were a case of the different species of native blister beetles. The Mexican highlands are quite rich in these forms, and it would seem that the descendants of the Spaniards in Mexico take a natural public interest in the relatives of the Spanish fly. At any rate, this interest exists to the exclusion of all other insects, so far as the Mexican national museum is concerned.

New Mexico and Arizona belong to the same natural region as the highlands of Mexico, and the following notes on nineteen species of meloids collected in those territories will be of interest. The specimens from Grant County, N. Mex., were collected by Mr. W. J. Howard, in 1882 , and formed a part of a collection donated by Hon. W. G. Ritch, ex-secretary of the Territory, to the Historical society, at Santa Fé, N. Mex.

Cysteodemus wislizeni Lec.-Found singly crawling on sandy mesa to eastward of Las Cruces, toward Organ mountains, August 2o, and other dates. This is a very peculiar spherical shaped species, of a brilliant blue or purple color, with more or less of metallic reflections. Det. by Liebeck.

Megetra vittata Lec.-A very large number of this large, lubber-like, black 
and red blister beetle were found on ground in a very restricted area at Pescado, on the Zuni Indian reservation, N. Mex., July 31, I892. They seem like a lubber-grasshopper edition of a blister beetle. The abdomens of the females were especially swollen and filled with eggs, as was seen by opening one. They are black with transverse red stripes or bands. A number of pairs were observed in coitu. Their numbers, and peculiar form and markings, make the occurrence an interesting one. Det. by Liebeck. A single specimen was found in the Organ Mountains, Doña Ana County, N. Mex., Nov. 26, 1892 , at the north end of the range near base, back of and east of San Augustine. One specimen was also found in the collection made by Mr. W. J. Howard in Grant County, N. Mex., in 1882.

Meloe sublaevis Lec.-A single specimen from Grant County, N. Mex. (W. J. H.). This has much the appearance of Megetra. It is wholly black, with short elytra, covering little more than two-fifths of the abdomen. Det. by Riley.

Nemognatha immaculata Say.-One from Grant County, N. Mex. (W. J. H.). It is very pale dilute yellowish in color, with tarsi and antennae darker. Det. by Riley.

Macrobasis longicollis Lec.-This is a large gray blister-beetle. Collected in Las Cruces. Det. by Riley.

Macrobasis ochrea Lec.-One specimen from Grant County, N. Mex. (W. J. H.). This is an elongate species, of a straw yellowish color. Det. by Riley.
Macrobasis gissleri Horn.-Found in the blooms of rucca baccata, May 15, I892. Region of the Organ Mountains, near Las Cruces, N. Mex. Several specimens. This is the species mentioned in Zoe, vol. iii, p. 114, as Epicauta cinctipennis with a query. Specimens were afterward determined by Dr. Riley as $M$. gissleri.

Epicauta pardalis Lec.-Found great numbers of this species bunched on low weeds and grass in a restricted area, along roadside just west of the continental divide, between Patterson and Gallo Spring, Socorro County, N. Mex., June 21, I892. Det by Liebeck. Epicauta maculata Say.-Several specimens found on plateau a few miles to the north of San Francisco Mountain, Arizona, July 5, 1892. Det. by Liebeck.

Epicauta funebris Horn.-Several specimens, Las Cruces, Oct. 24. On various weeds. Det. by Riley.

Epicauta corvina Lec.-Two specimens of this black species from Grant County, N. Mex. (W. J. H.). Det. by Riley.

Pyrota terminata Lec.-One from Sabinal, N. Mex., August 7, I892. It is pale straw yellow, with three large black markings on each elytron, the anterior one split into two. Head and thorax with more of an orange tinge. Two also from Grant County, N. Mex. (W. J. H.). Det. by Riley.

Pyrota postica Lec.-This is a large black and yellow meloid-see Insect life, vol. v, p. 40. It is light orange yellow, with four black dots on pro- 
thorax, two black spots at base of each elytron, and one very large subquadrate spot before tip. Tarsi black, and under side of thorax and abdomen more or less black. Occurs very numerously near Las Cruces, N. Mex., on Larrea mexicana, particularly on flowers. Det. by Liebeck.

Cantharis deserticola Horn.-This is a black meloid, with orange head and thorax. Three specimens from Grant County, N. Mex. (W. J. H.). Det. by Riley.

Cantharis nuttalli Say.-This is a beautiful metallic green species, the elytra with a greenish purple luster. The wing covers are rather tapering apically. One from Grant County, N. Mex. (W. J. H.). Det. by Riley.

Cantharis cyanipennis Say.-This is a purplish blue species, with tapering elytra, somewhat smaller than $C$. nuttalli. One from Grant County, N. Mex. (W. J. H.). Det. by Riley.

Cantharis biguttata Lec.-One specimen collected at Zuni Pueblo, N. Mex., July 29, I892. It is yellowish in color. Det. by Riley.

Cantharis sphaericollis Say.-Two specimens of this beautiful green species were found on San Francisco Mountain, Arizona, July 15, 1892. Western slope, probably about 10,000 feet. Det. by Liebeck.

Eupompha fissiceps Lec.-One from Las Cruces, on mesa toward Organ Mountains, July, r892, (E. C. Holmes). This is a beautiful bluish green metallic species, with head and legs rufous. The elytra are roughened. Det. by Riley.

\section{A PRELIMINARY LIST OF THE ACRIDIDAE OF NEW ENGLAND.}

\section{BY ALBERT P. MORSE, WELLESLEY, MASS.}

In the following list I have sought to aid the student beginning the study of this family by providing a catalogue and ready means of indicating, for exchange or other purpose, the species and more noticeable less important forms of locusts found in New England. While several points yet remain to be settled regarding the relations of certain forms and the identity of others, it is believed that the list will be found convenient to use and practically complete.
In order to make it as complete and correct as possible I shall be grateful for information of any errors and desirable or necessary additions. This desire, together with the hope that it will lead to wider interest in and a more thorough knowledge of the group, leads me to publish it at the present time.

The New England representatives of the family Acrididae are distributed in this list among five subfamilies, twentythree genera, forty-five well-defined 

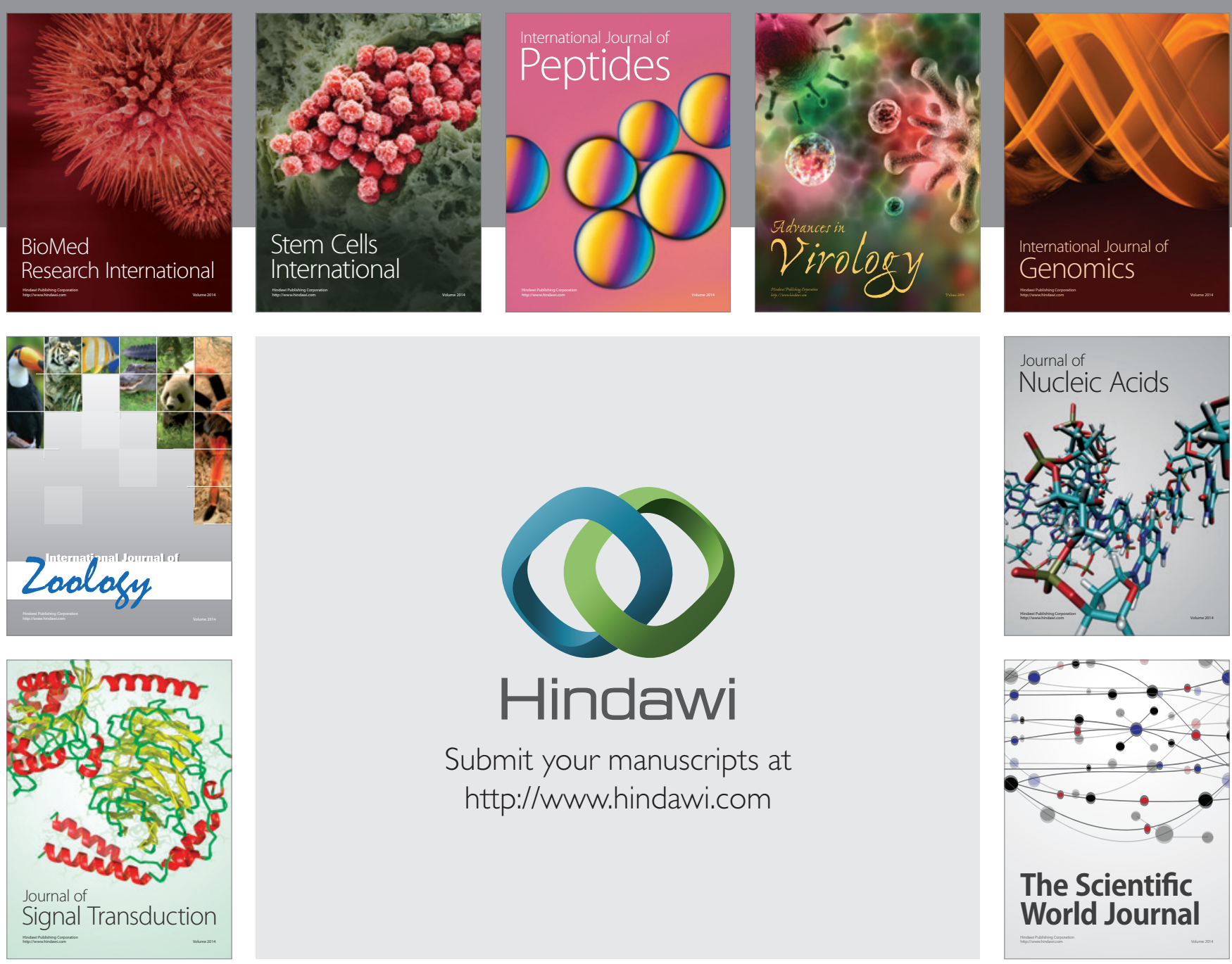

Submit your manuscripts at

http://www.hindawi.com
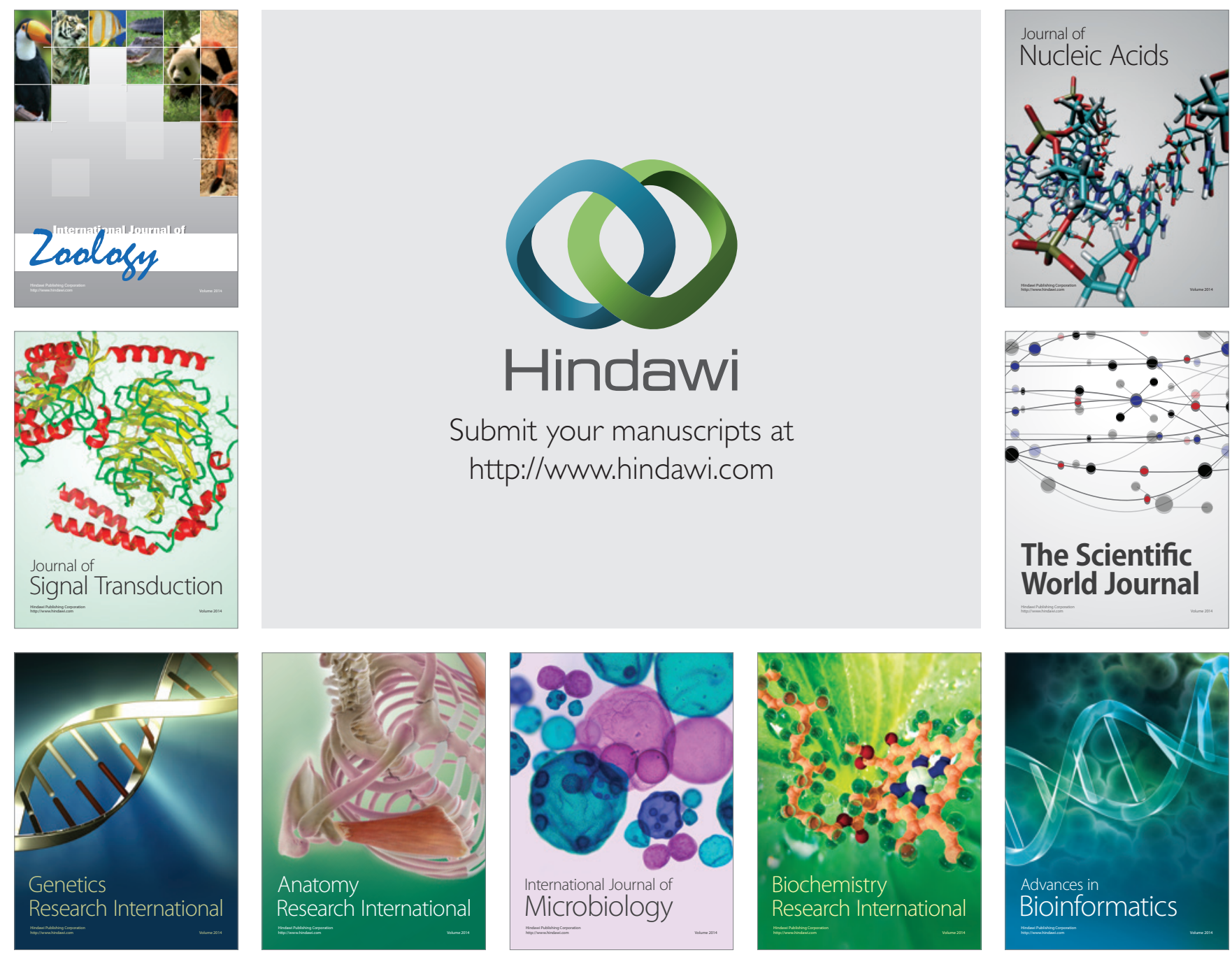

The Scientific World Journal
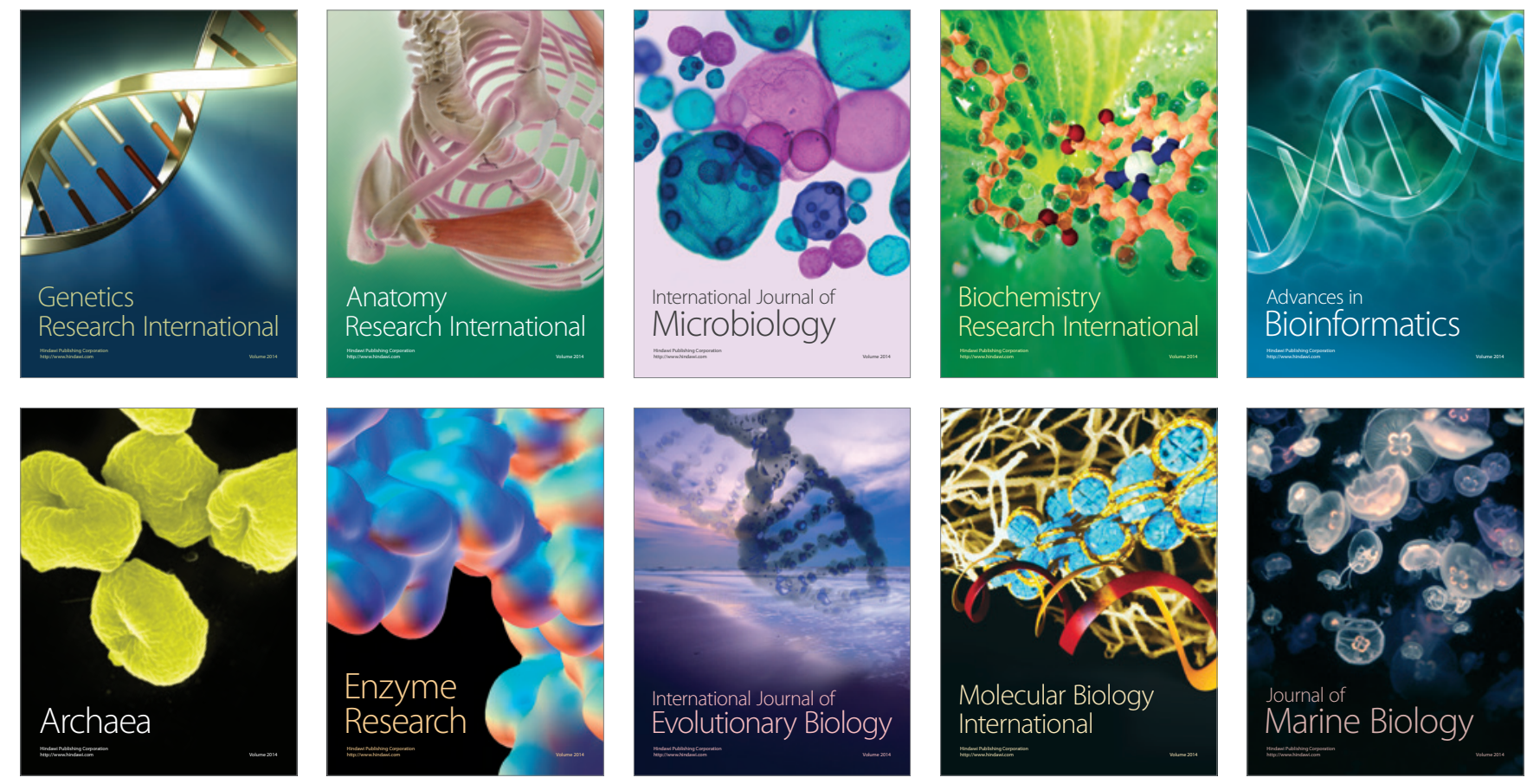